\title{
DEVELOPMENT OF Lutzomyia intermedia AND Lutzomyia longipalpis (DIPTERA: PSYCHODIDAE: PHLEBOTOMINAE) LARVAE IN DIFFERENT DIETS
}

\author{
WERMELINGER, E. D. ${ }^{1,2}$ and ZANUNCIO, J. C. ${ }^{2}$ \\ ${ }^{1}$ Departamento de Ciências Biológicas, Escola Nacional de Saúde Pública, Fundação Oswaldo Cruz, \\ Rua Leopoldo Bulhões, 1480, Manguinhos, CEP 21041-210, Rio de Janeiro, RJ, Brazil \\ ${ }^{2}$ Departamento de Biologia Animal, Universidade Federal de Viçosa, CEP 36571-000, \\ Viçosa, Minas Gerais, Brazil \\ Correspondence to: Eduardo Dias Wermelinger, Departamento de Ciências Biológicas, Escola Nacional de \\ Saúde Pública, Fundação Oswaldo Cruz, Rua Leopoldo Bulhões, 1480, Manguinhos, CEP 21041-210, \\ Rio de Janeiro, RJ, Brazil, e-mail: edw@ensp.fiocruz.br \\ Received October 25, 1999 - Accepted June 23, 2000 - Distributed August 31, 2001
}

\begin{abstract}
The objective of this research was to evaluate, in laboratory, the development of Lutzomyia intermedia and Lutzomyia longipalpis (Diptera: Psychodidae: Phlebotominae) larvae, vectors of leishmaniasis in Brazil, in the following diets: industrialized food for rabbits, dogs, hamsters and aquarium fishes, besides liver powder, cooked lettuce, wheat germ, beer yeast, oat, wheat bran and a diet denominated aged food. Except wheat bran for L. intermedia, all diets provided adequate development for both species, which showed that any of them can be used in laboratory insectaries for these insects. L. intermedia showed better development with most nutritious diets and both species presented better development with aged food. Fungi as an additional nutrient source for L. intermedia and L. longipalpis is suggested.
\end{abstract}

Key words: Phlebotominae, vectors, diets, fungi effects.

\section{RESUMO}

Desenvolvimento de larvas de Lutzomyia intermedia e de Lutzomyia longipalpis (Diptera: Psychodidae: Phlebotominae) em diferentes dietas

Neste trabalho, foi avaliado, em laboratório, o desenvolvimento de larvas de Lutzomyia intermedia e de Lutzomyia longipalpis (Diptera: Psychodidae: Phlebotominae), vetores de leishmanioses no Brasil, nas seguintes dietas: rações industrializadas para coelho, cachorro, hamster e peixe de aquário; pó de fígado, alface cozida, gérmem de trigo, levedo de cerveja, aveia, farelo de trigo e uma dieta denominada ração envelhecida. Com exceção do farelo de trigo para L. intermedia, todas as dietas mostraramse adequadas para uso em insetários para flebotomíneos. L. intermedia teve melhor desenvolvimento nas dietas mais nutritivas e ambas as espécies apresentaram melhor desempenho na ração envelhecida. A importância dos fungos como complemento alimentar para $L$. intermedia e $L$. longipalpis é sugerida.

Palavras-chave: Phlebotominae, vetores, dieta, efeito de fungos.

\section{INTRODUCTION}

The necessity to rear insects of economical importance has made the entomologists to improve different techniques to be used in insectaries. An important limitation for rearing leishmaniasis vec- tors is the necessity to have appropriate diets for their larva. Hertig \& Johnson (1961) stated that an appropriate food for larva of these insects represents one of the basic requirements in phlebotomine rearing facilities and Modi \& Tesh (1983) reported that larval diet is the most important factor 
to keep vigorous colonies of phlebotomine species. For this reason, many diets have been used to rear phlebotomine larvae (Barreto, 1942; Forattini, 1973; Sherlock \& Sherlock, 1972), but few studies have compared different diets aiming to select the better ones to rear such vectors. Besides, the lack of knowledge about many aspects of immature stages of leishmaniasis vectors represents an obstacle for the development of strategies for their control. For this reason, it is necessary to study diets to be used in phlebotomine insectaries as well as of their alimentary habits, which can help to understand their biology. The objective of this research was to study larval development of Lutzomyia intermedia and Lutzomyia longipalpis (Diptera: Psychodidae: Phlebotominae), vectors of the tegumentar and visceral leishmaniasis, respectivelly, in Brazil, with different diets.

\section{MATERIAL AND METHODS}

This research was carried out in laboratory conditions starting with groups of 100 eggs of $L$. intermedia and L. longipalpis per Petri dish with a 0.5 to $1.0 \mathrm{~cm}$ thick plaster layer as substratum. Humidity inside these Petri dishes was maintained above $90 \%$ by constant wetting the plaster with distilled water. These dishes were maintained in a closed plastic recipient lined with humidified paper filter. Such recipients were kept in the absence of light at $25^{\circ} \mathrm{C}$ in the phlebotomine insectary of the Department of Entomology of the Oswaldo Cruz Institut, in Rio de Janeiro, State of Rio de Janeiro, Brazil, from where eggs of $L$. intermedia and $L$. longipalpis were obtained for the development of this research. Breeding method for these phlebotomine species was originally described by Rangel et al. (1985).

The following diets were tested: industrialized food for rabbit, dogs, hamsters and aquarium fishes; liver powder, cooked lettuce, wheat germ, beer yeast, oat, wheat bran and a variation of a diet developed by Young et al. (1981), which we denominated aged food. Industrialized food was reduced to powder by manual trituration. Liver powder was obtained from a piece of cooked liver, dried in a stove and triturated. Cooked lettuce was dried out and grinded to powder, while oat and wheat bran were, only, reduced to powder. The aged food was prepared as a mixture of half/half feces and food of rabbits added with industrialized fish food aiming to enrich this diet.

A total of five Petri dish plates were used for each diet with L. longipalpis and six of them with L. intermedia. Number of pupae was counted in each Petri dish.

\section{RESULTS AND DISCUSSION}

Best results for L. longipalpis and L. intermedia were obtained with aged food (Table 1). This diet differs from all others because it has humus, obtained by decomposition of the mixture with intensive fungi growth, which seems to make it more nutritious and healthy for rearing phlebotomine larva. It can be accepted that the aged food is more similar to the natural substratum of phlebotomine larva than any other of the food tested. This diet was originally described by Young et al. (1981) for these insects and it was also used with some variations by Endris et al. (1982), Modi \& Tesh (1983), Chaniotis (1986) and Lawer et al. (1991) with excellent results. Besides Chaniotis (1986) registered a higher gonotrofic activity of females of Lutzomyia trapidoi (Diptera: Psychodidae) reared with this diet. Sherlock \& Sherlock (1959) observed that decomposed vegetable material or dry bovine feces presented better results for rearing L. longipalpis. For this reason such materials should be aged in incubator during some days before being used in diets for rearing flebotomine larva (Sherlock \& Sherlock, 1972).

Except for the aged food we considered all industrialized animal food tested (dog, rabbit, hamster and fish food) more nutritious than the others (lettuce, liver powder, wheat germ, beer yeast and wheat bran). In this way $L$. intermedia presented better development with most nutritious diets but this was not observed for L. longipalpis (Table 1).

Although the incidence of fungi has been observed in all diets it was not possible to quantify those with larger or smaller proliferation of these microorganisms. However, the presence of fungi in the wheat bran and in the aged food was sharply smaller. Since wheat bran can be considered a low value nutritional food this could explain the weak proliferation of fungi in this diet. Results of rearing L. intermedia with wheat bran were worst than with all other diets (Table 1). 
TABLE 1

Number of Lutzomyia intermedia and Lutzomyia longipalpis (Diptera: Psychodidae: Phlebotominae) pupa per Petri dish with different diets in laboratory.

\begin{tabular}{|c|c|c|}
\hline \multicolumn{3}{|c|}{ Lutzomyia intermedia } \\
\hline Diet & Number of pupae/Petri dish & Mean \\
\hline Aged food & $37-42-45-47-51-52$ & 45.6 \\
\hline Rabbit food & $28-30-35-36-43-56$ & 45.6 \\
\hline Dog food & $25-31-41-42-44-52$ & 39.1 \\
\hline Fish food & $19-25-38-40-42-45$ & 34.8 \\
\hline Hamster food & $15-25-27-29-36-52$ & 30.6 \\
\hline Liver powder & $12-15-16-25-41-50$ & 26.5 \\
\hline Wheat germ & $12-16-16-19-25-32$ & 20.0 \\
\hline Cooked lettuce & $05-06-11-16-31-42$ & 18.5 \\
\hline Beer yeast & $13-16-16-17-18-27$ & 17.8 \\
\hline Oat & $06-06-08-15-20-26$ & 13.5 \\
\hline Wheat bran & 02-02-02-04-04-07 & 03.5 \\
\hline \multicolumn{3}{|c|}{ Lutzomyia longipalpis } \\
\hline Diet & Number of pupae/Petri dish & Mean \\
\hline Aged food & $35-58-60-61-69$ & 56.6 \\
\hline Liver powder & $24-45-56-67-71$ & 52.6 \\
\hline Cooked lettuce & $46-49-51-54-57$ & 51.4 \\
\hline Oat & $30-36-55-56-62$ & 47.8 \\
\hline Dog food & $35-50-50-51-53$ & 47.8 \\
\hline Wheat bran & $29-34-47-50-61$ & 44.2 \\
\hline Hamster food & $30-35-37-44-48$ & 38.8 \\
\hline Fish food & $26-27-28-51-55$ & 37.4 \\
\hline Wheat germ & $23-30-35-45-49$ & 36.4 \\
\hline Beer yeast & $24-34-34-43-45$ & 36.0 \\
\hline Rabbit food & $25-27-27-27-41$ & 29.4 \\
\hline
\end{tabular}

We suppose that fungi can represent an important alimentary complement for L intermedia. Although most authors consider that fungi proliferation in diets represents a serious problem for rearing larva of phlebotomine, their importance as food for such larva has not yet been well considered and discussed. It is not clear if the presence of fungi in the diets is beneficial or not for phlebotomine larva although it has been observed that larva of these insects usually feed on fungi and their risk in presence of these microorganisms is higher during first instars. It is possible that these larvae as detritivores can get nutrients from fungi, although they have some risks searching for this type of food, mainly in environments with high levels of fungi proliferation specially during their first instars. The low value nutritious plus the lack of fungi proliferation in wheat bran could explain the lower performance of $L$. intermedia in this diet. Unlike L. intermedia, L. longipalpis presented good results with wheat bran. Could this indicate that L. longipalpis can grow with lower nutrients requirement than $L$. intermedia or does L. longipalpis carries more effective simbiontes in their alimentary canal? L. longipalpis is one of the easiest New World phlebotomine species reared in insectary 
(Killick-Kendrick et al., 1991). Can this be, partly, explained because larva of this species are able to grow in more unfavorable nutritional conditions? These results seem to demonstrate that alimentary requirements of flebotomine larva vary among species and can indicate that each species of this group can develop in different natural conditions or that they prefer different substrata or types of organic matter. This behavior could contribute to reduce competition among phlebotomine species in natural conditions, which could in turn favor their reproduction and survival in field conditions.

Acknowledgments - To all members of the Sandfly Insectary of the Leishmaniasis and Onchocerciasis Vector Laboratory of the Entomology Department of the Oswaldo Cruz Institut and to the Conselho Nacional de Desenvolvimento Científico e Tecnológico (CNPq).

\section{REFERENCES}

BARRETO, M. P., 1942, Contribuição para o estudo da biologia dos flebótomos em condições experimentais (Diptera Psychodidae). Tese de Doutorado, Fac. Med. USP, São Paulo, Brasil.

CHANIOTIS, B. H., 1986, Successful colonization of the sandfly Lutzomyia trapidoi (Diptera: Psychodidae), with enhancement of its gonotrophic activity. J. Med. Entomol., 23: 163-166.

ENDRIS, R. G., PERKINS, P. V., YOUNG, D. G. \& JOHNSON, R. N., 1982, Techniques for laboratory rearing of sand flies (Diptera: Psychodidae). Mosq. News, 42: $400-407$
FORATtini, O. P., 1973, Entomologia Médica. Vol. 4. Edusp, São Paulo, 658p.

HERTIG, M. \& JOHNSON, P. T., 1961, The rearing of Phlebotomus sandflies (Diptera: Psychodidae). Ann. Ent. Soc. Amer., 54: 753-763.

KILLICK-KENDRICK, R., MAROLI, M. \& KILLICKKENDRICK, M., 1991, Bibliography on the colonization of phlebotomine sandflies. Parassitol, 33(Suppl. 1): 321-333

LAWER, P. G., ROWTON, E. D., PERKINS, P. V., JOHNSON, R. N. \& YOUNG, D. G., 1991, Recent advances in laboratory mass rearing of phlebotomine sand flies. Parassitol., 33(Suppl. 1): 361-364.

MODI, G. B. \& TESH, R. B., 1983, A simple technique for mass rea-ring Lutzomyia longipalpis and Phlebotomus papatasi (Diptera: Psychodidae) in the laboratory. J. M. Entomol., 20: 568-569.

RANGEL, E. F., SOUZA, N. A., WERMELINGER, E. D. \& BARBOSA, A. F., 1985, Estabelecimento de colônia, em laboratório de Lutzomyia intermedia Lutz \& Neiva, 1912. Mem. Inst. Oswaldo Cruz, 80: 219-226.

SHERLOCK, I. A. \& SHERLOCK, V. A., 1959, Criação e biologia em laboratório do Phlebotomus longipalpis (Lutz \& Neiva, 1912). Rev. Brasil. Biol., 19: 229250.

SHERLOCK, I. A. \& SHERLOCK, V. A., 1972, Métodos práticos para criação de flebotomíneos em laboratório. Rev. Brasil. Biol., 32: 209-217.

YOUNG, D. G., PERKING, P. V. \& ENDRIS, R. G., 1981, A larval diet for rearing phlebotomine sand flies (Diptera: Psychodidae). J. Med. Entomol., 18: 446. 